\title{
Conservation status of the current state of cryptogamous diversity in Mongolia
}

\author{
Enkhtuya Ochirbat ${ }^{*}$ \\ Botanical Garden and Research Institute of the Mongolian Academy of Sciences, 14200 Ulan Bator, \\ Mongolia
}

\begin{abstract}
In recent years, cryptogamous biodiversity and scop their areal in Mongolia have begun to decline due to human activities, global warming and desertification, and have become one of the reasons for the threat of their extinction. At the regional level, a study was carried out to determine their conservation status in accordance with the criteria of the International Union for the Conservation of Nature and Natural Resources. First of all, according to the assessment results, 221 species (5.0\%) need protection.
\end{abstract}

Today in our country 7725 species of biodiversity of plants and fungi are known. About 60 percent of them or 4525 species, belong to lower cryptogamous plants. This includes 580 species of mosses, 2,248 species of algae, 630 species of fungi and 1,067 species of lichens. $[1,7,8,9]$. However, only $0.35 \%$ of all of these cryptogamma representatives are protected $[3,5,6]$, which is completely unsatisfactory. And so, in 2018-2020, for the first time in Mongolia, 373 endangered species or $8.2 \%$ of all lower cryptogamous species were assessed in accordance with the criteria of the International Union for Conservation of Nature and Natural Resources, IUCN (IUCN).

According to the assessment results, it was found that $49(8.4 \%)$ species of mosses; 41 $(1.8 \%)$ species of algae; $82(7.8 \%)$ species of lichens and $49(7.7 \%)$ species of fungi, or a total of 221 species $(5.0 \%)$ need protective measures (Table 1).

Table 1. Conservation status rating of cryptogamous diversity included in the regional Red List in Mongolia as endangered (2020)

\begin{tabular}{|c|c|c|c|c|c|}
\hline \multirow{2}{*}{$\begin{array}{c}\text { Threat rating in } \\
\text { the Red List of } \\
\text { Mongolia }\end{array}$} & \multicolumn{4}{|c|}{ Percentage of the total number of species } & \multirow{2}{*}{$\begin{array}{c}\text { Total } \\
\text { amount }\end{array}$} \\
\cline { 2 - 5 } & Mosses & Algae & Lichens & Fungi & 37 \\
\hline CR & 10 & 5 & 16 & 6 & 81 \\
\hline EN & 22 & 14 & 32 & 13 & 103 \\
\hline VU & 17 & 22 & 34 & 30 & $221(5.0 \%)$ \\
\hline Total & $49(8.4 \%)$ & $41(1.8 \%)$ & $82(7.6 \%)$ & $49(7.7 \%)$ & 20 \\
\hline
\end{tabular}

\footnotetext{
* Corresponding author: tuyabot0613@gmail.com
} 


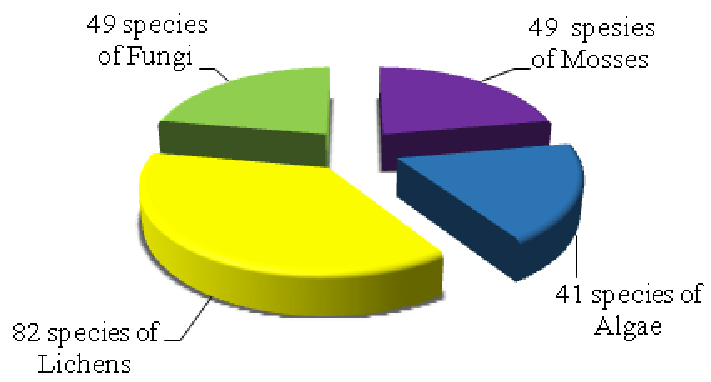

Fig. 1. The percentage of taxa representatives of the total number of endangered cryptogamma species included in the Red List of Mongolia

In Mongolia, in accordance with the categories and criteria of the IUCN Red List (IUCN) were determined on the basis of general principles and taking into account the individual characteristics of each taxon. The categories of the protected status of species of cryptogamma plants have been established, 37 species or $16.8 \%$ are "on the verge of complete extinction or endangered (CR), 81 species or 36.6 percent are "endangered" (EN), 103 species or 46.6 percent are "vulnerable" (VU).

Based on the status of the threat, the main reasons for their threat and measures to protect them were developed [4, 7]. Based on the above results, $118(2.6 \%)$ species of cryptogamous lower plants are classified as "very rare", and 103 (2.3\%) as "rare" (Table 2).

Table 2. Data on the number of species of mosses, algae, lichens and fungi from the Red List in need of protection (2020)

\begin{tabular}{|c|c|c|c|c|c|c|c|c|c|c|c|c|c|c|c|}
\hline \multirow{3}{*}{ 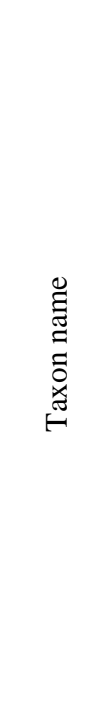 } & \multicolumn{4}{|c|}{$\begin{array}{l}\text { Threatened species } \\
\text { status }\end{array}$} & \multicolumn{7}{|c|}{$\begin{array}{l}\text { Rating of threats according to the } \\
\text { criteria of the International Red List }\end{array}$} & \multicolumn{2}{|c|}{$\begin{array}{c}\text { In } \\
\text { Appendix } \\
\text { to the } \\
\text { Natural } \\
\text { Plants Act }\end{array}$} & \multicolumn{2}{|c|}{$\begin{array}{l}\text { In } \\
\text { Appendix } \\
\text { to the } \\
\text { Natural } \\
\text { Plants Act }\end{array}$} \\
\hline & \multicolumn{2}{|c|}{ 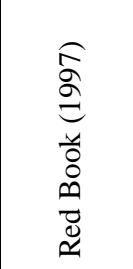 } & \multicolumn{2}{|c|}{ 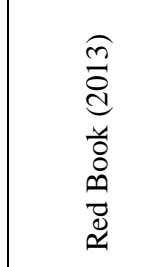 } & \multicolumn{3}{|c|}{ 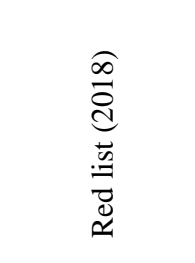 } & \multicolumn{3}{|c|}{ 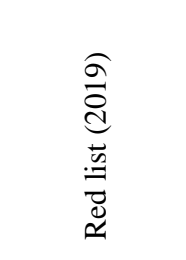 } & \multirow[t]{2}{*}{ 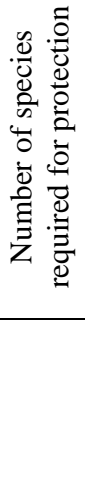 } & & & \multicolumn{2}{|c|}{ 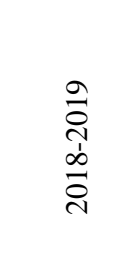 } \\
\hline & 焉 $\frac{\lambda}{0}$ & 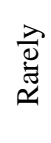 & $\begin{array}{l}2 \\
\overrightarrow{0} \\
>\end{array}$ & 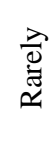 & ૈ & ZII & $?$ & Ư & 壼 & 3 & & 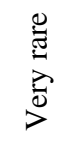 & שّ̋ & 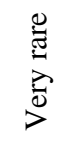 & گँّ \\
\hline Mosses & - & 4 & - & 12 & 1 & 10 & 4 & 9 & 12 & 13 & 49 & - & 4 & 32 & 17 \\
\hline Algae & - & - & 1 & 17 & 5 & 12 & 18 & 0 & 2 & 4 & 41 & 1 & 4 & 19 & 22 \\
\hline Lichens & - & 12 & 3 & 12 & 4 & 14 & 14 & 12 & 18 & 20 & 82 & - & 12 & 48 & 34 \\
\hline Fungi & - & - & - & 12 & 3 & 4 & 14 & 3 & 9 & 16 & 49 & - & 6 & 19 & 30 \\
\hline
\end{tabular}




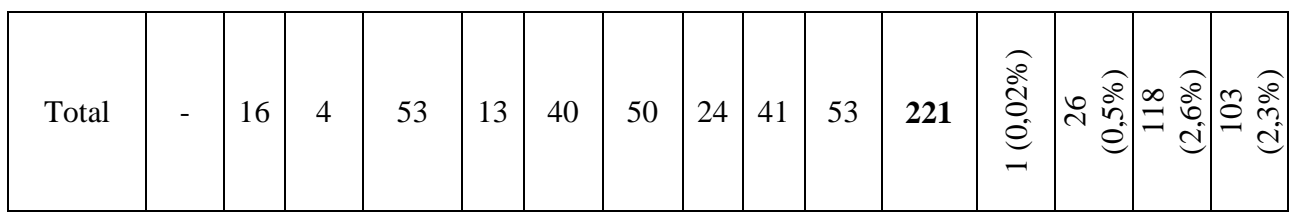

Thus, Table 3 summarizes the results of assessing the conservation status of the cryptogamic, i.e., the lowest plant in Mongolia, and their threat status in accordance with the criteria of the International Red List.

Table 3. Assessment of the conservation status of the current state Cryptogamous Diversity in Mongolia (2020)

\begin{tabular}{|c|c|c|c|c|c|c|c|c|c|c|}
\hline \multirow{4}{*}{ 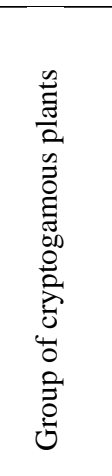 } & \multicolumn{7}{|c|}{\begin{tabular}{|c|} 
Assessment according to the criteria of the international Red \\
List $(2018 / 2020)$
\end{tabular}} & \multirow{3}{*}{\multicolumn{3}{|c|}{ 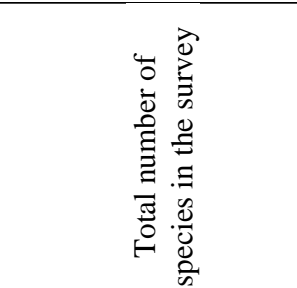 }} \\
\hline & \multicolumn{3}{|c|}{ Rating threat status } & \multicolumn{4}{|c|}{ No threat rating } & & & \\
\hline & \multicolumn{3}{|c|}{$\begin{array}{l}\text { Number of species } \\
\text { required for protection }\end{array}$} & \multicolumn{4}{|c|}{$\begin{array}{l}\text { Number of species outside } \\
\text { protection }\end{array}$} & & & \\
\hline & CR & EN & VU & NT & $\mathrm{LC}$ & DD & NA & 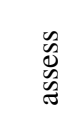 & 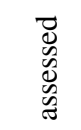 & $\frac{\vec{d}}{\tilde{g}}$ \\
\hline Mosses & 10 & 22 & 17 & 133 & 232 & 116 & 24 & 580 & 562 & 18 \\
\hline Algae & 5 & 14 & 22 & 73 & 1472 & 147 & 315 & 2248 & 2208 & 40 \\
\hline Lichens & 16 & 32 & 34 & 226 & 125 & 597 & - & 1067 & 1030 & - \\
\hline Fungi & 6 & 13 & 30 & 13 & 45 & 327 & 196 & 630 & 630 & - \\
\hline Total & 37 & 81 & 103 & 445 & 1874 & 1187 & 535 & 4525 & 4430 & 48 \\
\hline
\end{tabular}

It is noteworthy that a Red List of endangered lower plant species that require conservation measures has been compiled, and a basis has been developed to update the list of very rare and endangered lower plants in the Natural Plants Law of Mongolia. Extensive work is expected to be done on $538(11.8 \%)$ of the $1,187(26.2 \%)$ assessed as lack of information (DD) and $535(11.8 \%)$ as not assessed (NA).

\section{References}

1. Biodiversity of Mongolia. List of species of plants, fungi and microorganisms in Mongolia (Mongolica, 2019)

2. Law on Natural Plants. Collection of laws (Ulan Bator, 1995)

3. Red List of Cryptogamic Plants of Mongolia. Third series. Regional Red List Series, Vol. 12 (Ulan Bator, Bambi San, 2020)

4. Red Data Book of Mongolia (Ulaanbaatar, Admon, 1997)

5. Red Data Book of Mongolia (Ulaanbaatar, Admon, 2013) 
6. Red List of Mongolian Plants. Second series. Regional series of Red bills., Vol. 11 (Mongolia, 2019)

7. Ts. Ts. Tsegmed, Flora of mosses of Mongolia (Moscow, 2010)

8. N. S. Golubkova, Conspectus of Lichen of Mongolia (Leningrad, Nauka, 1981)

9. N. Kherlenchimeg, G. Burenbaatar, Conspectus of the higher fungi (Mongolia, Ulaanbaatar, 2017)

10. IUCN. Guidelines for using the IUCN Red List Categories and Criteria: version 13 (February, 2017). IUCN Standards and Petitions Subcommittee of the IUCN Species Survival Commission, Gland, Switzerland. Available at http://www.iucnredlist.org 